\title{
Responding to poverty through education and teacher education initiatives: a critical evaluation of key trends in government policy in England 1997-2015
}

Katharine Burn* and Ann Childs

Department of Education, University of Oxford, Oxford UK

* Corresponding author. University of Oxford, Department of Education, 15 Norham Gardens, Oxford OX2 6PY, UK, Email: katharine.burn@education.ox.ac.uk 


\begin{abstract}
This paper presents a comparative critique of key education and teacher education policies in England adopted by New Labour (1997-2010) and the Coalition government (2010-15). It focuses on direct measures intended to alleviate the effects of poverty on young people's educational outcomes, and on teacher education policies with implications for preparing teachers to tackle such problems. It questions the consistency, coherence and effectiveness of the policies pursued by each administration and analyses the similarities and differences between them. Particular attention is paid to the conceptions of professional knowledge and educational research that underpin their assumptions about the role of teachers' professional learning in seeking to break the link between young people's socio-economic status and their educational outcomes. While policies implemented by both administrations are deeply imbued with neo-liberal perspectives, our analysis highlights important differences, the effects of which may become more apparent as the Conservatives exercise their independent authority over education.
\end{abstract}

\title{
Key words
}

Teacher education policy; poverty; economically disadvantaged; pre-service teacher education; New Labour; Coalition government

\section{Introduction}

This paper presents a critical examination of government policies in education and teacher education in England that address, explicitly or implicitly, issues of poverty and disadvantage. It covers the period 1997-2015, dealing first with the policies of successive Labour administrations and then with those of the Coalition Government. While all political parties within those administrations and each successive 
Secretary of State for Education expressed their commitment to addressing the educational inequalities associated with socio-economic disadvantage and while each intervened in significant ways in initial teacher education (ITE), only some of the initiatives undertaken to address educational inequalities also had specific implications for teacher preparation or professional development. The paper therefore tackles each issue in turn: first questioning the coherence and consistency of Labour policies (1997- 2010) concerned with addressing the impact of poverty on education, and then applying the same critique to interventions in teacher education with implications for preparing teachers to respond effectively to the barriers to learning associated with economic disadvantage. A similar two-pronged approach is taken to the Coalition Government (2010-15). The paper concludes by examining similarities and differences between the two types of administration, demonstrating that while they were both committed to pursuing neo-liberal policies that combined increasingly tight regulation in some domains with principles of diversity and 'consumer' choice in others - thereby exemplifying classic features of a quasi-market system (Levacic 1995) - there were also highly significant differences between them. These differences can be seen not only in the extent to which schools alone were regarded as responsible for, or capable of, overcoming the educational inequalities that arise from socio-economic disadvantage, but also in their diverse conceptions of the kinds of professional knowledge with which teachers need to be equipped in order to contribute effectively to that endeavour. In turn, those different conceptions also gave rise to profoundly different views of research-based or theoretical knowledge and of the roles that universities should play, both in its creation and effective dissemination.

\section{The Labour Government 1997-2010}

Incoherence and inconsistency in the plethora of 'Third way' education policies addressing issues of poverty and disadvantage 
The Labour Party that triumphed in the landslide victory of May 1997 had promised a dramatic break with the neo-liberal policies of the preceding Conservative administrations, which they characterised and condemned as a 'ruthless free-for-all' (Power and Whitty 1999, 599), essentially premised on the laissezfaire principles of free-market capitalism. While this characterisation failed to acknowledge the role of state intervention and tightening regulation that the Conservatives had also introduced (most obviously in the form of a national curriculum), it allowed New Labour to promise an alternative 'third way': balancing market principles of choice and competition with appropriate, well-informed direction. Education policy would be formulated, it was claimed, "on the basis of "what works" rather than being driven by any one ideological approach' (Power and Whitty, 1999, 599). In fact, as Power and Whitty went on to argue, the extent to which Labour embarked on a new course is debatable: despite some 'Old Labour thinking, New Labour's 'strategies [were] largely an extension of the second way "neoliberalism" of the previous Conservative governments' (535).

Powell $(2000,46)$ has shown that New Labour policies concerned with combatting the effects of poverty and disadvantage tended to be couched in 'the terms of inclusion and exclusion'. Equal opportunities discourse was "constructed around the problem of how to enable "them" ("the different") to overcome barriers that prevent them from becoming like "us" (“the normal”)' (48). The language of 'inclusion' as a response to economic disadvantage was also prevalent within educational policy, as Furlong (2005), has noted:

Raising educational standards has been one of the government's key priorities because at one and the same time education is seen as being able to create economic growth in the flexible, knowledge-based economies of the twenty-first century, and to promote social inclusion by creating pathways out of poverty (123).

The Labour Government's declared commitment to tackle the educational inequalities associated with socio-economic disadvantage was quickly matched by a plethora of new initiatives. Education Action 
Zones (EAZ) were introduced in June 1998 in 25 different areas, as a 'fresh approach' to the 'deep-seated problems' of improving the performance of schools in challenging circumstances through 'partnerships of schools, the business sector, local authorities and community organisations' (DFEE 1988, para 1.2). The Sure Start initiative, announced the same year and initially operating as a series of local programmes, was designed to 'give additional professional help to families with young children in areas of poverty' (Power and Whitty1999, 537), focusing on the improvement of health services and family support, including increased provision of childcare, alongside early education. Parents were seen as important partners in determining the nature of the local programmes. A third initiative, the Excellence in Cities (EiC) programme, established in March 1999, was built on the principle of schools in inner city and deprived urban areas working together to raise standards. Additional funding was spent on learning mentors and learning support units, alongside provision for those pupils designated as 'gifted and talented' and access to high quality ICT resources in new City Learning Centres.

This series of specific programmes was followed in Labour's second administration by a much more wide-ranging and ambitious programme, Every Child Matters (ECM), which called for extensive interprofessional collaboration. Launched in 2003 (across England and Wales), it encompassed children and young adults and, as Williams $(2004,407)$ explains, it argued for 'a more universal approach to children: propos[ing] universal prevention and early intervention, rather than just targeted protection, and draw[ing] these into the goal of ending child poverty and enabling every child to reach their potential'. At its heart was a commitment to inter-professional collaboration: a network of support, including health and social services working closely with schools, to combat the effects of disadvantage. Within ECM, the Sure Start local programmes were replaced by Sure Start Children's Centres, operated by local authorities, providing easy access to a full range of services.

While this range of programmes indicates a strong commitment to tackling educational disadvantage, it has been argued that 'the sheer number of separate initiatives' led to 'a lack of overall coherence' in policy direction (Walford 2006, 5). This can be seen in the different assumptions reflected in each 
initiative about the impact of poverty and how it could be redressed. While $E i C$, for example, seemed to be based on the premise that compensatory educational interventions alone could overcome the barriers to learning created by economic deprivation, Sure Start and ECM were underpinned by an awareness that the transformation of young people's educational outcomes also depended on action in other arenas, including health services and access to high-quality childcare. They also reflected different views about the most effective agents in addressing educational inequalities associated with poverty. While some programmes, such as $E A Z$ were based on the principles of public-private partnership, encouraging business investment in local communities, Sure Start initially sought to engage and empower parents as active partners, only to find that the Sure Start Children's Centres developed under ECM effectively vested power in local authorities. According to Glass (2005) the emphasis of ECM also shifted from concern with child development to the provision of childcare, reflecting an assumption that parental inclusion within the labour market would contribute most effectively to improving children's educational outcomes.

More damning, perhaps, than lack of coherence is Walford's (2006) claim that other educational policies pursued by New Labour actually tended 'in the opposite direction', effectively increasing inequality. On these grounds he particularly indicted the extension of diversity within secondary education through the introduction of more specialist schools. Pioneered by the previous Conservative administration in its creation of sponsored City Technology Colleges, this was a policy with strong neo-liberal resonances, both in its involvement of the private sector and in its emphasis on parental choice and the promotion of competition between different kinds of provider. Labour extended the policy, first by creating further specialist designations, such as Beacon Schools - high-performing schools given additional funding to share their good practice with others identified as 'failing' - and in 2000 by establishing the first in a series of 'academies' - privately sponsored schools (independent of the then local education authorities) in areas of socio-economic disadvantage. While these sponsored academies were explicitly intended to address long-standing problems of under-achievement, it is important to examine Walford's claim that 
they may well have increased, rather than decreased, educational inequalities. This followed Ball, Bowe and Gewirtz's (1996) earlier demonstration that increases in diversity of provision, combined with the operation of parental choice, could operate to reinforce inequality and hierarchies of social class.) Where such detailed analysis has been undertaken, for example, by Gorard $(2005,2014)$, the conclusion seems to be that the earliest academies did not in fact lead to an increase in segregation, but this was only because:

The schools selected at the outset were among the most disadvantaged and so where they changed their intake as a result of Academisation, this was no threat to local levels of socio-economic segregation between schools. For example, where new Academies ended up taking a smaller share of local free school meal (FSM) eligible pupils, this meant neighbouring schools had to take more and so the local clustering of poorer children in specific schools would reduce.

(Gorard 2014, 269).

Unfortunately, however, in terms of addressing educational disadvantage, Gorard also concluded that there was 'no evidence' that the earliest academies were, in general, 'performing any better for equivalent pupils than the schools they replaced' (Gorard 2005, 369).

New Labour teacher education policies: mandated standards with the capacity to enrich teachers' knowledge undermined by the diversification of training routes

New Labour's teacher education policies reflected the same combination of state regulation and freemarket mechanisms that had been employed by the preceding Conservative administrations. Where the Conservatives had intervened in the early 1990s to specify the precise number of days that postgraduate student-teachers should spend in school-based training (DFE 1992), the Labour government imposed tighter forms of control by intervening in the content of ITE (Furlong et al. 2000) - establishing national standards for the award of Qualified Teacher Status and setting out a national curriculum for ITE 
programmes. The neo-liberal, market-based elements of Labour's policy can be discerned, as Childs (2013) has discussed elsewhere, in its diversification of the routes into teaching, through the creation of new school-based routes: the employment-based Graduate Teacher Programme (GTP) and Teach First.

Unsurprisingly, the contrast between the regulatory tendencies (towards formalising the content of ITE programmes) and the more liberal promotion of choice and competition (embedded in the diversification of ITE training routes) created profound tensions in terms of preparing new teachers to work effectively with young people living in poverty. While the former provided considerable scope to examine the ways in which social class, poverty and disadvantage combine to affect the educational outcomes of pupils and to investigate research claims about the kinds of interventions that have most potential to make an impact, the latter tended to inhibit any sustained focus on such theoretical or research-based perspectives.

The potential inherent in the new Standards for Qualified Teacher Status (TTA 2003) derived from requirements related to understanding the diverse needs of young people as a precursor to effective personalised provision. Standard Q18, for example, required teachers to 'understand how children and young people develop' and 'to recognise specific sorts of developmental, social, religious, ethnic, cultural and linguistic influences that impact on the progress and well-being of the young people whom they teach'. Standards Q19 and Q25 both acknowledged clearly that the 'promotion of equality and inclusion' depended on the capacity to 'take practical account of diversity'.

In theory the force of these standards was backed by Ofsted inspections and other accountability systems, such as the annual survey of newly qualified teachers. Yet it must be acknowledged that presentation of the issue in terms of 'inclusion' and the enumeration (in Standard Q18) of the very wide range of influences impacting on child development about which student-teachers were expected to learn, make it difficult to judge the extent to which ITE providers' efforts were focused specifically on equipping student-teachers to understand the nature of the interaction between poverty and education or to translate 
those understandings into particular pedagogical responses. The best that can be claimed, perhaps, is that the Universities Council for the Education of Teachers at least acknowledged and mapped out the profound implications of the ECM agenda in terms of teachers' professional knowledge. Kirk and Broadfoot (2006), for example, outlined six implications for ITE:

(i) A need for an analysis of the policy context of ECM

(ii) A need to reassess the place of knowledge in teacher education

(iii) A need for student-teachers to undergo 'sustained study of the theoretical perspectives of child development, on human learning, on the environmental and other obstacles to human flourishing, on conditions which maximize learning, and on the manifold ways in which learning is facilitated and managed'

(iv) A need to develop an understanding of the inter-professional context

(v) An emphasis on developing skills in students-teachers which 'give greater prominence to the subtleties of the interpersonal interaction skills required in discussions in interprofessional contexts'

(vi) The need for ITE to rework their partnership arrangements, making it possible for them to draw on the necessary knowledge and expertise in different contexts. (12-13)

Although none of these are the exclusive domain of either university or school partners, arguably implications (i), (ii) and (iii) required significant input from different kinds of research traditions (sociological as well as psychological) which universities were well-placed to provide. Yet it was precisely this kind of sustained theoretical analysis and research-informed perspective that was rendered problematic by the diversification of ITE, since the new routes all reduced the role of universities. The reduced scope for this kind of analysis was evident even within the Teach First programme despite the scheme's declared commitment to breaking the link between parental wealth and children's educational outcomes. 
Inspired by Teach for America, but adapted to local circumstances (Ellis et al. 2016), Teach First sought to overcome the 'scourge' (Wigdortz, 2012) of educational underachievement among the poor by recruiting well-qualified graduates, prepared to commit to teaching for at least two years in a London secondary school in 'challenging circumstances' - as defined with reference either to the school's public examination results at $16+$ or to the proportion of pupils eligible for Free School Meals. While recruitment was successful (allowing the gradual expansion permitted by the government, from 186 participants in 2003 to 485 in 2009), the location of most professional learning 'on-the-job' meant that there was relatively little time and few sustained opportunities for psychological or sociological examination of the ways in which poverty and structural inequalities tend to impact on young people's engagement with, and capacity to exploit, different kinds of educational provision. With limited opportunity for university-based study - approximately 20 days within the introductory six-week 'Summer Institute' (with other days devoted to school induction and school-centred learning) and just six further study days over the course of the year - the strongest influences on new recruits' understanding and practice were likely to be the perspectives that they encountered within school, although this may have been mediated by the programme's explicit ethos.

Occupational socialization has been shown to be the strongest factor counteracting attempts at educating innovative teachers, even in tightly-integrated partnership ITE programmes (Wideen, Mayer-Smith and Moon 1998; Brouwer and Korthagen 2005) designed to facilitate the use of research to interrogate existing practices. Where the scope for alternative perspectives is significantly reduced, so too is the potential to challenge prevailing assumptions. The programme thus lacked precisely the opportunity for 'sustained study of the theoretical perspectives of child development, on human learning, on the environmental and other obstacles to human flourishing, on conditions which maximize learning' that Kirk and Broadfoot $(2006,12)$ had regarded as necessary within the ECM agenda. 
It could be argued that the explicit commitment of Teach First to breaking the connection between educational attainment and parental income may have helped to challenge the essentially conservative dynamic of an apprenticeship training model. Yet the fact that a strong component of the Teach First 'vision' was the presumed need to 'raise pupils' aspirations' (teachfirst.org/leadership development programme 2015) meant that the programme tended to operate with an essentially unhelpful deficit model, of the kind condemned by Gorski (2012). The assumption that educational outcomes could be transformed by an emphasis on raising young people's aspirations and changing their attitudes has also been shown, in a series of research reviews commissioned by the Joseph Rowntree Foundation, to lack any secure evidence (Cummings et al. 2012; Carter-Wall and Whitfield 2012).

\section{The Coalition government 2010-2015}

Coalition contradictions between freedom and regulation in responding to educational inequalities: a new compensatory initiative backed by new accountability mechanisms

Key figures in the Coalition Government, established in May 2010, declared their commitment to ensuring social mobility and emphasised the essential role of education in overcoming disadvantage. The first Education Secretary, the Conservative Michael Gove, proclaimed 'the gap in attainment between rich and poor' to be 'a scandal' (Gove, 2010b), while the Liberal Democrat Schools Minister, David Laws, professed similar determination to break down 'this stubborn attainment gap between richer and poorer pupils' (Laws 2014). The policy solutions that they advanced remained distinctly neo-liberal in their emphasis on diversification, but this was combined with a neo-conservative drive towards a more traditional curriculum and more rigorous testing. They were also accompanied by a new compensatory initiative, which promised increased educational funding for all pupils identified as economically disadvantaged, while reinforcing the drive to narrow the gap with new accountability mechanisms. 
In terms of the diversification of schooling a fundamental change was made to the academy policy, allowing any school rated 'good' or 'outstanding' by Ofsted to apply for conversion to academy status. While early converters received some additional resources, the policy was essentially promoted in terms of the freedoms it offered: 'less bureaucracy and an opportunity to thrive, free from interference from government' (Gove 2011b). The new 'converter Academies' were still bound by admissions criteria set for all state schools, but could develop their own curriculum - rather than being constrained by the National Curriculum, which was simultaneously being made more rigorous!

In a more radical move, the Coalition also permitted the establishment of entirely new 'free' schools. Officially enjoying the same 'freedoms' as academies, and required to be run on a not-for profit basis, they could be established by a wide range of organisations, including businesses, but also encompassing charities, universities, existing academies or independent schools, community and faith groups, parents and teachers. The policy emphasis on wresting control of education from local government was underlined, however, by the fact that no new schools (of any kind) could henceforward be established by local authorities.

While these policies, as we have noted, could be presented in neo-liberal terms as driving improvement by increasing diversification and parental choice, Gorard (2014) has observed that under the Coalition, the process of 'academisation' was essentially 'driven by the purported school improvement agenda'. The declared commitment to addressing the relationship between educational outcomes and socio-economic inequalities that had officially underpinned previous sponsored conversions of 'failing' schools in areas of economic disadvantage was 'now largely ignored' (2014, 269).

In marked contrast to this neglect, a much more explicit commitment to 'closing the gap' in educational outcomes between the poor and their more affluent peers was embodied in the Pupil Premium Grant. Although this was merely the latest in a long line of 'compensatory' initiatives (Mortimore and Whitty 1997), it was much more wide-ranging than many because of its application to every eligible student, 
wherever they lived. Originally championed by the Liberal Democrats, the policy provided specific funds - 'an additional $£ 2.5$ billion a year' (Laws 2010) - that schools were expected to use to improve the educational outcomes of pupils in receipt of Free School Meals. The policy was accepted as part of the Coalition Agreement, and instituted in the first year of government.

In examining this range of policies - some of which represented the continuation and expansion of policies driven forward by New Labour - the over-riding picture is again one of inconsistency, with the impact of certain policies effectively undermining the stated aims of others. As Gorard has demonstrated, the expansion of the academies programme emphatically failed to decrease segregation. Data drawn from the Annual Schools Census (1989-2012), the Department of Education School performance tables (2004-2012) and the National Pupil Database revealed that 51\% of Converter Academies took less than half of their 'fair share' of FSM pupils - in contrast to only $3 \%$ of Sponsor-led academies (Gorard 2014, 273). (Although Gorard did not conclude that the presence of particular kinds of academies actually exacerbated problems of segregation - noting, in fact, that any causal link might well operate in the opposite direction - his work demonstrated that local authorities with both types of academy were linked to higher levels of segregation than local authorities with a higher proportion of maintained schools.

The introduction of the Pupil Premium Grant did, however, appear to represent a more determined and focused policy initiative, reinforced in a variety of ways (with implications for teacher education), but perhaps most obviously by accountability mechanisms. The formal inspection framework was revised to ensure that judgments about schools' effectiveness took particular account of the achievement of pupils registered as eligible for Free School Meals at any point in the previous six years. In July 2014 Ofsted declared that 'headteachers know that their schools will not receive a positive judgement unless they demonstrate that they are focused on improving outcomes for pupils eligible for the pupil premium' (Ofsted 2014, 4). Although the same report claimed that the funding was 'making a difference in many 
schools', it conceded that it would take more time to establish whether it would actually lead to a narrowing in the attainment gap.

\section{One consistent emphasis in Coalition policies: increasing the role of schools and reducing that of universities in both the production of research and the process of teacher education}

The Coalition's teacher education policies also reflected a continued commitment to diversification - both in the range of applicants they sought and in the development of new routes - that ran counter to their regulatory tendencies in other respects. More significantly, they represented the continuation and intensification of a sustained attack on the role of universities. As Furlong (2005) has previously argued, Conservative policies in this respect had long been driven by ideological objectives, but their ferocity escalated after the Coalition came to power, with Gove explicitly condemning certain 'academics who have helped run the university departments of education' as members of 'the Blob', 'Marxist sympathisers' and 'enemies of promise' (Gove 2013).

In opposition, the Conservatives' teacher education policy had primarily been expressed in terms of improving the quality of teachers because of the essential role they were expected to play in raising the achievement and social mobility of the most disadvantaged (Gove 2010a). Improvement was proposed through diversification of the profession: the recruitment of ex-service personnel and high achieving business people, through 'Troops to Teachers' and a 'Teach Now' initiative (an expansion of Teach First). As Childs and Menter reflect, while the emphasis on diversifying the range of applicants had a 'more neo-liberal slant', policies designed to bring troops into teaching to improve discipline and a simultaneous focus, in new teacher standards, on developing teachers' subject knowledge 'resonate more with neo-conservative perspectives of tradition and control' $(2013,106)$. 
The ‘Troops to Teachers' programmes were formally launched in June 2013 (DFE 2013) while the Teach First programme nearly trebled in size over the five years of the parliament, to reach 1400 participants (including primary and early years' teachers), placed in ten different regions (teachfirst.org/about our history 2015). Although the DFE did not in fact establish a 'Teach Now' programme, Teach First also began targeting career changers, with such success that they accounted for $22 \%$ of the participants enrolling in 2014 (Teach First, 2014).

While these policies were primarily concerned with the nature of the teaching workforce, the principle of diversification was also applied in a much more radical way to the organisational structures and recruitment processes of ITE, through the establishment of School Direct. The thrust of this policy towards 'school-led' ITE was consistent with moves made by the Conservatives in the early 1990s, establishing that that all postgraduate trainees (on secondary programmes) should spend at least twothirds of their time in school (DFE 1992), but the emphasis in Gove's reforms on school leadership of ITE implied a fundamental shift in power relations, and organisational arrangements.

Gove sought to justify an increased role for schools by drawing on Barber and Mourshed's (2010) report for McKinsey:

What they found was that the best systems embed professional and talent development in schools... In Finland trainees receive extensive classroom teaching practice under the guidance and supervision of experienced teachers. In Singapore I saw trainees learning how to improve their craft and strengthen their classroom management skills by observing the very best teachers at work in the classroom. All of these nations currently outperform us educationally and the emphasis they place on both intensive school-based classroom training and continual school-based professional development is at the heart of their success (Gove 2011a). 
The policy was signalled in the Government White paper, The Importance of Teaching (DFE 2010b) and fleshed out in a subsequent implementation plan (DFE 2011). It was to be facilitated by creating a network of Teaching Schools, expected to 'lead the school system in training and developing outstanding teachers' (DFE 2011) - an expectation that extended beyond initial training, to further professional development of 'teachers, support staff and head teachers' and 'the raising of standards through school-toschool support' (DFE 2014). School Direct training placements would be allocated directly to Teaching School partnerships, which might choose whether or not to collaborate with a particular HEI. The School Direct routes expanded with extraordinary speed, accounting for 351 of secondary trainees in 2012-13 (little more than $1 \%$ of the total cohort) and for 17,609 places allocated for 2015-16 (just over 40\%) (DFE 2013). This far exceeded Gove's original suggestion of 10,000 by the end of the parliament (Gove 2012).

As Furlong has noted, this further diversification of routes into teaching was matched by the introduction of a 'new and slimmed-down list of teachers' standards' $(2013,44)$. While reference was still made to essential knowledge and understanding that should underpin teachers' practice - including understanding of 'how a range of factors can inhibit pupils' ability to learn' - the main thrust of the reform was to emphasise teachers' demonstrable competences. Extensive guidance (some 150 pages) that had accompanied the previous standards was simply removed, offering maximum flexibility to ITE providers in the design of their programme.

A more extreme form of flexibility had, however, already been offered to schools, some two months earlier, with the announcement in July 2012 that academies and free schools could choose to by-pass ITE altogether and simply recruit untrained teachers. This additional freedom amply illustrates the tensions inherent in the Coalition's blend of neo-liberal and neo-conservative policies, which seek to regulate the nature and content of ITE programmes even as they liberate schools from the obligation to engage with them at all. The essential contradictions are further highlighted by Gove's decision in 2015 to commission a review of Initial Teacher Training, which recommended the establishment of a new core curriculum to be included in any ITE programme (Carter 2015). The inconsistencies evident in these two decisions 
precisely mirrored those playing out in relation to the school curriculum: a review process largely premised on Hirsch's notion of 'core knowledge' - intended to equip all young people with the knowledge that would give them access to power (Gibb, 2015) - conducted at the same time as academies and free schools were exempted from its mandate.

As argued earlier, any move to make the role of universities more marginal within ITE has the potential to reduce the theoretical understandings of beginning teachers about the ways in which issues of poverty, social class and disadvantage impact on young people's capacity and commitment to engage with particular kinds of educational opportunities. This is particularly problematic if the alternative perspectives that are offered serve to perpetuate unhelpful assumptions about those living in poverty. Moreover, there is little evidence in the international comparisons on which the Coalition Government originally drew, that reducing the university-based components of ITE would improve their effectiveness. Indeed Gove's (2012b) appeal to practices in Finland and Singapore dramatically over-stated the role of school-based provision in those countries and obscured their fundamental commitment to developing research-informed knowledge and understanding and the capacity to subject routine practices to systematic critical evaluation.

In Finland, for example, the successive periods of classroom experience accounted for only about a third of the ITE programme (Sahlberg 2012) - half as much as in existing postgraduate programmes in England. In summarising the Finnish's programme's key features, Sahlberg argued that it was supported by 'scientific knowledge' and focused on 'thinking processes and cognitive skills employed in conducting research' (Jakku-Sihvonen \& Niemi 2006). He particularly alluded to the 'systemic integration of scientific educational knowledge, didactics and practice in a manner that enables teacher to enhance their pedagogical thinking, evidence-based decision making and engagement in the scientific community of educators' (Sahlberg 2012,6). All prospective teachers were required to achieve a full Master's degree, demonstrating knowledge and understanding of the 'advanced fields of educational science' and the 'interdisciplinary nature of educational practice' as well as their own capacity to 'design, conduct and 
present original research on practical or theoretical aspects of education' $(2012,11)$. This, it was argued, would equip them not only to adopt a research-orientation towards their own practice, but also to evaluate the findings of others' research, discerning its value in interpreting and responding to the particular classroom situations that they faced.

It is true that the notion of teachers as researchers as well as users of research was endorsed by the Coalition's policies but even as it apparently embraced this idea, the government consistently sought to reduce the role of universities, not only excluding them from ITE, but marginalising them in the production of research - since that too could be entrusted to schools. Indeed designation as a Teaching School carried with it a formal commitment to:

- $\quad$ build on existing research and contribute to alliance and wider priorities

- base new initiatives within your alliance on existing evidence and ensure you can measure them

- $\quad$ work with other teaching schools in your area, or nationally, where appropriate

- ensure that your staff use existing evidence

- allow your staff the time and support they need take part in research and development activities

- $\quad$ share learning from research and development work with the wider school system (DFE 2014)

While the use of 'existing evidence' might well imply reliance on academic research, the Coalition's consistent policy drive to reduce the influence of universities and to prioritise certain kinds of research over others was reflected in two other policy initiatives. Both were related to the generation of knowledge intended to equip teachers to overcome the inequalities in educational outcomes associated with socioeconomic disadvantage and they took the form of significant financial contributions to the Educational Endowment Foundation (EEF) and to the 'Closing the Gap Test and Learn' project.

Although officially an independent grant-making charity, the establishment of the EEF was supported by a Department for Education grant of $£ 110$ million (DFE 2010a). Its declared objective was to 'break the 
link between family income and educational achievement, ensuring that children from all backgrounds can fulfil their potential' which it sought to achieve by:

- Identifying and funding promising educational innovations that address the needs of disadvantaged children;

- Evaluating these innovations to extend and secure the evidence on what works and can be made to work at scale;

- Encouraging schools, government, charities, and others to apply evidence and adopt innovations found to be effective. (EEF 2011)

Closing the Gap (CTG), a sustained research initiative involving Teaching Schools and their local alliances, was similarly intended 'to help improve the evidence-base for what works in closing the attainment gap for disadvantaged pupils' while also stimulating 'robust research and development in schools' (curee.co 2015) .

At first, in contrast to the thrust of ITE policies which seemed to be encouraging schools to assert their independence of universities (or at least their authority within school/HEI partnerships), the rhetoric with which CTG was launched appeared to reflect a commitment to 'strengthening relationships' between schools and HEIs, building tighter links 'between the teaching profession and universities' thereby 'helping to develop the academic standing of the teaching profession' (CfBT.com 2015). The initial phase was undertaken by the University of Durham, working in conjunction with the Centre for the Use of Research and Evidence in Education (CUREE), to identify a series of potentially powerful interventions that schools could trial in a two-year programme (CUREE 2015). The capability phase was entrusted to the CfBT Education Trust (now the Education Development Trust) and to the University of Oxford, with the latter specifically expected to support small-scale professional enquiry into pupils' and teachers' 
experience of the interventions, including analysis of the reasons for their success (or failure) (Childs, Firth and Thompson, 2015).

Although this approach might seem to represent a well-coordinated commitment both to tackling the educational outcomes of socio-economic disadvantage and to developing a more research-literate teaching profession, capable of sustaining the continued professional learning of its members, in effect its key focus on finding interventions which 'work' to close the gap reflected the discredited assumption (Mortimore and Whitty 1997) 'that social inequality and 'gaps' in outcomes can be eliminated through educational interventions alone' (Ellis et al. 2016, 60). This is the same assumption that underpinned the publication of the EEF/Sutton Trust Toolkit (Higgins et al.2014), designed to provide an easily accessed and straightforward guide to research evidence about the effectiveness of particular interventions (presented in relation to their cost).

While publication of the toolkit obviously reflected an endorsement of research - much of it conducted by university-based researchers - its very nature meant that it could only encompass particular kinds of research: studies able to generate quantitative measures of impact. A similar premise underpinned CTG, which was based on the use of randomised control trials to determine which of the seven selected interventions 'worked' to close the gap. The role of the university was limited, in Durham's case, to working with CUREE to select the interventions and, in Oxford's case, to provide regional training (each typically lasting one day, at three separate points within the two-year project) to strengthen and enhance the Teaching Schools' capacity to engage in research. However, such limited contact, three points over two years, with participants representing 673 Teaching Schools made it difficult to ensure the kind of significant and sustained interactions necessary to build the 'stronger links between universities and schools' (CfBT.com 2015) that had originally been promised. In addition, even though existing university partners of Teaching Schools were formally invited to training events, attendance was sparse and the direct involvement of universities other than Oxford was not mentioned in the final project report 
(Churches 2015). Any potential that there might have been to bring in more critical examination of the ways in which poverty impacts on young people's engagement in education, or (more radically) to question the assumption that educational innovations alone, without attention to structural inequalities, can reverse established patterns of relative achievement between advantaged and disadvantaged pupils seems not to have been realised.

By reducing the role of educational research to a narrow technicist notion of 'what works' the Coalition government restricted the scope to equip teachers with the full range of knowledge and understanding necessary to tackle the barriers to learning that derive from socio-economic disadvantage and structural inequalities. Their actions reflected an essential distrust of theoretical perspectives informed by sociological or socio-cultural research. While the Coalition retained an explicit commitment to the use of 'research' within ITE - reflected within the suggested ITE curriculum proposed by Carter (2015) - there was no requirement for teachers in free schools or academies ever to engage with that curriculum since they were not obliged to gain a teaching qualification. While universities still appeared to have some role as the suppliers of research, they were essentially marginalised and excluded from any role in developing teachers' abilities to evaluate research critically or to implement it in contextually sensitive ways. Teachers were expected to draw on research as expert technicians, having been told 'what works'. While they might play a part in generating the evidence that informed pronouncements, they were effectively barred from contributing to those judgements and received little encouragement to engage with the questions of why or how particular strategies work and thus of how they might be adapted or developed to make them more effective, or effective in different contexts.

\section{Similarities and differences between Labour and Coalition policies}

Having examined the policies espoused and enacted by both the New Labour and Coalition governments across the period 1997-2015, we conclude by clarifying the extent of the similarities and differences between them. While both are undoubtedly deeply imbued with a neo-liberal perspective, there are in fact 
profound differences between them, the effects of which are likely to become more apparent over the next few years as the Conservatives exercise their independent authority over education.

A shared commitment to compensatory policies and the establishment of a quasi-market through diversification and choice

Both New Labour and the Coalition governments sought to address the gap between the outcomes of wealthier and poorer pupils by directing resources into specific educational provision for the most disadvantaged. The essential difference, however, was that while successive Labour administrations channelled funding into particular regional initiatives such as the Education Action Zones and Excellence in Cities programme, the Pupil Premium Grant, linked funding to individual pupils and thus effectively made all schools clearly accountable for the achievement of children identified as economically disadvantaged. The funding and the accountability measures associated with it undoubtedly succeeded in focusing attention on the educational outcomes of young people living in poverty, even in more affluent areas, although it is accepted that little impact can yet be seen on their attainment (Ofsted 2014).

A second broad similarity is that both New Labour and the Coalition governments argued that diversification of educational provision and increased parental choice would serve to drive up standards (through competition between schools) and thus to improve the educational outcomes of disadvantaged pupils. As we have noted, this neo-liberal idea was originally borrowed from the Conservatives by New Labour. The first Conservative, privately-sponsored City Technology College, was followed under New Labour by a range of specialist schools, and specifically by a series of privately-sponsored academies that replaced 'failed' schools in areas of socio-economic disadvantage. Although the achievements of these particular academies continue to be debated, the best that can be said of them is that they did not exacerbate the problems of disadvantage by increasing social segregation (Gorard 2005). Little more can be claimed of the extraordinary wave of diversification unleashed by the Coalition's academy 
programme. As Gorard (2014) has demonstrated there is still no evidence either that they have reduced social segregation or that they have achieved any kind of differential impact in terms of value-added scores.

The principle of diversification was also applied by both New Labour and the Coalition government to the issue of teacher quality, which was regarded as another important means of improving the educational outcomes of those living in poverty. Teach First was enthusiastically embraced by policy-makers in all parties because of its avowed commitment and demonstrable success in attracting 'high-quality graduates into teaching, expanding by 2014 to become the largest recruiter of graduates in the UK, (Birchall 2014). The scheme's most dramatic expansion took place, however, under the Coalition government, which was also responsible for the 'revolutionary' changes (Gove 2012) heralded by the introduction of School Direct and the establishment of the Teaching School alliances that underpinned this fundamental shift of responsibilities within ITE.

Profoundly different conceptions of universities' role impacting on teachers' theoretical understandings of the educational impact of poverty and disadvantage

While previous Labour governments had promoted a number of employment-based routes into teaching, these were always seen as 'alternative' routes intended to make the profession more accessible to particular kinds of career changers or mature applicants; they were never intended to replace established partnership programmes, nor were they driven by the ideological opposition to the role of universities in ITE that characterised some of the more intemperate pronouncements of Coalition ministers (see, for example, Gove, 2013). While the extraordinary expansion of School Direct in fact concealed considerable diversity of provision (allowing some well-established partnerships to maintain their essential character), the contribution of universities within teacher preparation was effectively marginalised in many contexts, and the stability of its continuing provision called into question. Despite 
the early protestations of the Schools Minister, Nick Gibb, that the DFE was not 'abandoning universities' (Gibb, 2012) and the affirmation by the Carter Review (2015) of the importance of teachers learning to use research, the role assigned to universities in teacher education was essentially reduced in the Coalition's policies to the provision of research findings. These, it was presumed, should be presented not as theoretical models of children's learning to be drawn on in interpreting and responding to learners' needs in any particular context, but as clearly delineated and empirically validated teaching strategies ideally validated through the use of randomised control trials. Unfortunately, although the use of such research methods does not by definition preclude consideration of the specific contexts in which certain strategies do and do not work, the emphasis on simplification of the research to make it accessible tends to promote the expectation that certain strategies should be universally applicable. Moreover, the fact that randomised control trials cannot in themselves explain why or how particular strategies work also leaves teachers (who have been told merely that they do) poorly equipped to adapt and or modify them appropriately if the need arises.

The same differences between Labour and the Coalition (in terms of their conception of the kinds of knowledge and understanding that teachers need) are also reflected in changes that each made to the standards for award of Qualified Teacher Status (DFE 2012). While revisions under Labour included consideration of the knowledge and understanding that teachers would need to respond effectively to the ECM agenda (TTA 2003), the new standards issued by the Coalition (DFE 2012) paid relatively little attention to teachers' underlying knowledge and understanding of the barriers to learning faced by young people in particular circumstances. Even when the DFE reflected again on the kinds of knowledge on which effective teaching would depend and accepted the recommendations of the Carter Review (2015) that greater attention should be paid within the ITE curriculum to knowledge of child and adolescent development, no specific reference was made to any kind of sociological understanding of social class or of the psychological implications of deprivation. As Diane Reay has argued: 
With no access to sociological and historical understanding of social class and in particular the positioning of the working classes within education, initial teacher trainees are left ill informed ... and ill equipped to broach, let alone tackle, the greatest problem the education system faces: that of working class educational underachievement, alienation and disaffection. (Reay 2006, 303)

It is unsurprising, therefore, that despite the range of policy initiatives detailed here, there were few signs of sustained progress in the endeavour that came to be increasingly narrowly framed in terms of closing the 'achievement gap'. While the overall failure might be attributed to the limited time for which some interventions were sustained, the most consistent policies across the whole period were essentially based on establishing a quasi-market: promising increased freedom and diversity in order to maximise 'choice', while effectively seeking to mandate achievement through punitive accountability mechanisms. Not only is the claim that diversification tends to reduce the effects of disadvantage widely disputed (Feinberg and Lubienksi 2009), but these policies are also premised on the discredited assumption that the efforts of schools alone can redress the effects of wider structural inequalities. While schools undoubtedly do make a significant difference to the outcomes of pupils living in poverty (Mortimore and Whitty 1997), and have an essential role to play in equipping new entrants to the profession to contribute effectively to that work, there is little evidence to suggest that they will become any more effective by assuming sole responsibility for it. Indeed the consistent message to be drawn from a recent collection of studies examining international teacher education programmes that have achieved notable success in preparing teachers to work in high poverty schools (Lampert and Burnett 2016) is that their effectiveness in challenging unhelpful deficit models depends on providing beginning teachers with sustained opportunities to examine the nature of poverty in specific contexts (including its intersection with other factors such as race and social class). As Lampert and Bruce's (2016) collection richly demonstrates, this is a process facilitated by serious engagement with appropriate theoretical frameworks and with the kind of reflexive practice promoted by practitioner research training. These are precisely the components of 
teacher preparation that are lost in the policy drive towards on-the-job training; a drive with enthusiastic promoters elsewhere (Zeichner 2014); but so far most passionately embraced by the Coalition government in England - and its Conservative successor. 


\section{References}

Ball, S.J., R. Bowe, and S. Gewirtz. 1996. "Circuits of schooling: a sociological exploration of parental choice of school in social class contexts." Sociological Review 43: 53-78.

Mourshed, M., C. Chijioke, and M. Barber. 2010. How the world's most improved school systems keep getting better. New York, NY: McKinsey \& Company.

Birchall, M. 2014. The Times Top 100 Graduate Employers 2014-15. London: High Fliers Publications.

Brouwer, N. and F. Korthagen. 2005. "Can teacher education make a difference?" American Education Research Journal 42 (1): 153-224.

Carter A. 2015. Carter review of initial teacher training (ITT). London: DFE.

Carter-Wall, C. and G. Whitfield. 2012. The Role of Aspirations, Attitudes and Behaviours in Closing the Educational Attainment Gap. Joseph Rowntree Foundation. Accessed November 5, 2014. http://www.jrf.org.uk/publications/aspirations-attitudes-educational-attainment-roundup

Childs, A. 2013. "The work of teacher educators: an English policy perspective." Journal of Education for Teaching 39 (3): 314-328.

Childs, A., R. Firth and I. Thompson. 2015. "Who and why? Motives and agendas for key stakeholders." Paper presented at the British Educational Research Association Conference, Belfast, September 2015.

Childs, A. and I. Menter. 2013. "Teacher Education in $21^{\text {st }}$ Century England - A Case Study in Neoliberal Public Policy”. Revista Española de Educación Comparada 22.

Churches, R. (2016) Closing the Gap: test and learn. London, DFE. https://www.gov.uk/government/uploads/system/uploads/attachment data/file/495580/closing the gap t est_and_learn_full_report.pdf

Cummings, C., K. Laing, J. McLaughlin, I. Papps, L. Todd, and Woolner, P. 2012. Can changing aspirations and attitudes impact on educational attainment. Joseph Rowntree Foundation. Accessed November 5, 2014. http://www.jrf.org.uk/sites/files/jrf/education-attainment-interventions-full.pdf

CfBt.com 2015. Accessed 5 November http://www.cfbt.com/en-GB/What-we-do/Schoolimprovement/Teacher-development

Curee.co. 2015. Accessed 5 November. http://www.curee.co.uk/ctg/overview

DFE. 1992. Initial Teacher Training (Secondary Phase) Circular 9/92. London: DFE.

DFE. 2010a. Press release 3 November 2010 Accessed November 5, 2015.

https://www.gov.uk/government/news/new-endowment-fund-to-turn-around-weakest-schools-and-raisestandards-for-disadvantaged-pupils 
DFE. 2010b. The Importance of Teaching. The Schools White Paper 2010. London: The Stationery Office.

DFE. 2011. Training Our Next Generation of Outstanding Teachers. London: The Stationery Office.

DFE. 2012 Teachers' Standards. Accessed 5 November, 2015:

https://www.gov.uk/government/uploads/system/uploads/attachment_data/file/208682/Teachers_Standar ds_2013.pdf\#

DFE. 2013. Initial Teacher Training Performance Profiles: academic year 2012 to 2013. Accessed November 5, 2015. https://www.gov.uk/government/collections/statistics-teacher-training

DFE. 2014. Teaching schools: a guide for potential applicants, National College for Teaching and Leadership. Accessed 5 November 5, 2015. http://www.education.gov.uk/nationalcollege/index/supportfor-schools/teachingschools.htm

DFEE. 1998. Handbook for Education Action Zones. London: DFEE.

EEF. 2011. Challenge for the new Education Endowment Foundation laid bare. Accessed 5 November, 2015. https://educationendowmentfoundation.org.uk/news/challenge-for-the-new-education-endowmentfoundation-laid-bare/

Ellis, V., M. Maguire, T.A. Trippesatd, Y. Liu, X. Yang and K. Zeichner. 2016. "Teaching other people's children, elsewhere, for a while: the rhetoric of a travelling educational reform." Journal of Education Policy. 31 (1): 60-80.

Feinberg, W. and C. Lubienski. 2009. School Choice Policies and Outcomes: Empirical and Philosophical Perspectives. New York: State University of New York Press.

Furlong, J. 2005. "New Labour and teacher education: the end of an era." Oxford Review of Education 21 (1): 119-134.

Furlong, J. 2013. "Globalisation, Neliberailsm and the Reform of Teacher Education in England." The Educational Forum 77: 28-50.

Furlong, J., L. Barton, S. Miles, C. Whiting, and G. Whitty. 2000. Teacher Education in Transition: Reforming Teaching Professionalism. Buckingham: Open University Press.

Gibb, N. 2012. Oral Evidence at the Education Select Committee 14 March 2012. Accessed November 5, 2015. http://www.publications.parliament.uk/pa/cm201012/cmselect/cmeduc/1515/120314.htm

Gibb, N (2015) Welcome address to E.D. Hirsh, Policy Exchange Annual Lecture on Education, 17 September, 2015. Accessed 5 November 2015: http://www.policyexchange.org.uk/modevents/item/theannual-education-lecture-with-e-d-hirsch

Glass, N. 2005. Surely some mistake? The Guardian 5 January. Accessed 5 November 2015

http://www.theguardian.com/society/2005/jan/05/guardiansocietysupplement.childrensservices 
Gorard, S. 2005. “Academies as the 'future of schooling': is this an evidence-based policy?" Journal of Education Policy 20 (3): 369-377.

Gorard, S. 2014. "The link between Academies in England, pupil outcomes and local patterns of socioeconomic segregation between schools." Research Papers in Education 29 (3): 268-284.

Gorski, P.C. 2012. "Perceiving the Problem of Poverty and Schooling: Deconstructing the Class Stereotypes that Mis-Shape Education Practice and Policy." Equity and Excellence in Education 45 (2): 302-319.

Gove, M. 2010a. Michael Gove to the Local Government Association. Accessed 5 November, 2015. https://www.gov.uk/government/speeches/michael-gove-to-the-local-government-association

Gove, M. 2010b. Speech to the Westminster Academy, $9^{\text {th }}$ September 2010. Accessed 5 November, 2015. https://www.gov.uk/government/speeches/michael-gove-to-westminster-academy

Gove, M. 2011a. Michael Gove to National College. Accessed 5 November, 2015. https://www.gov.uk/government/speeches/michael-gove-to-the-national-college

Gove, M. 2011b. Education and Economic Success Speech to the Education World forum. Accessed 5 November, 2015. https://community.oecd.org/docs/DOC-20237

Gove, M. 2012. National College annual conference $14^{\text {th }}$ June 2012. Accessed 5 November, 2015. http://www.education.gov.uk/inthenews/speeches/a00210308/michael-gove-at-the-national-collegeannual-conference

Gove, M. (2013) “'I refuse to surrender to the Marxist teachers hell-bent on destroying our schools': Education Secretary berates 'the new enemies of promise' for opposing his plans" Mail Online, 22 March. Accessed 5 November, 2015. http://www.dailymail.co.uk/debate/article-2298146/I-refuse-surrenderMarxist-teachers-hell-bent-destroying-schools-Education-Secretary-berates-new-enemies-promiseopposing-plans.html

Higgins, S., M. Katsipataki, D. Kokotsaki, R. Coleman, L. E. Major, and R. Coe. 2014. The Sutton TrustEducation Endowment Foundation Teaching and Learning Toolkit. London: Education Endowment Foundation. Retrieved from:

https://educationendowmentfoundation.org.uk/uploads/toolkit/EEF_Toolkit_21st_November_2014.pdf

Hutchings, M., U. Maylor, H. Mendick, I. Menter and S.Smart. 2006. An evaluation of innovative approaches to teacher training on the Teach First programme: Final report commissioned by the Training and Development Agency for Schools. London: Institute for Policy Studies in Education, London Metropolitan University.

Jakku-Sihvonen, R. and H. Niemi. (eds) 2006. Research-based teacher education in Finland: Reflections by Finnish teacher educators. Turku: Finnish Educational Research Association.

Kirk, G. And P. Broadfoot. 2006. "ECM and teacher education: towards a UCET position paper." Paper presented at the UCET Annual November Conference, Daventry 2006. 
Lampert, J., and B. Burnett. (eds) 2016. Teacher Education for High Poverty School. Switzerland:

Springer International Publishing

Laws, D. 2010. Address to the Association of Teachers and Lecturers, 29 March 2010. Accessed 5

November, 2015. https://www.atl.org.uk/Images/David\%20Laws\%20at\%20ATL\%20conference\%20$\% 2029$ th\%20March\%202010.pdf

Laws, D. 2014. Speech on Grammar Schools 19 June 2014. Accessed 5 November, 2015. https://www.gov.uk/government/speeches/david-laws-speech-on-grammar-schools

Levacic, R. 1995. Local Management of Schools: analysis and practice. Buckingham: Open University Press.

Mortimore, P. and G. Whitty. 1997. Can School Improvement Overcome the Effects of Disadvantage? London: University of London, Institute of Education.

Ofsted. 2014 The pupil premium: an update (Reference no:140088), The Office for Standards in Education, Children's Services and Skills. Accessed 5 November, 2015.

https://www.gov.uk/government/publications/the-pupil-premium-an-update

Powell, M. 2000. "New labour and the third way in the British welfare state: a new and distinctive approach.” Critical Social Policy 20: 39-60.

Power, S. and G. Whitty. 1999. "New Labour's education policy: first, second or third way?" Journal of Education Policy 14 (5): 535-546.

Reay, D. 2006. "The Zombie Stalking English Schools: social class and educational inequality." British Journal of Educational Studies 54 (2): 288-307.

Sahlberg, P. 2012. "The most wanted: teachers and teacher education in Finland." In Teacher Education around the World: Changing policies and practices, edited by L. Darling-Hammond and A. Lieberman. Abingdon: Routledge.

Teacher Training Agency. 2003. Qualifying to Teach: Professional Standards for Qualified Teacher Status and Requirements for Initial Teacher Training. London: TTA.

Teachfirst.org/leadership development programme, 2015 Accessed 5 November. http://graduates.teachfirst.org.uk/leadership-development-programme

Teachfirst.org/about our history. 2015 Accessed 5 November. http://www.teachfirst.org.uk/about/ourhistory

Teach First. 2014. Change career, change lives. Accessed 5 November, 2015. http://www.teachfirst.org.uk/leaders-life/our-career-changers

Walford, G. 2006. Education and the Labour Government: An evaluation of two terms. Abingdon: Routledge.

Wideen, M., J. Mayer-Smith, and B. Moon. 1998. "A critical analysis of the research on learning to teach: making the case for an ecological perspective on inquiry." Review of Educational Research 68: 130-178. 
Wigdortz, B. 2012. Success Against the Odds: five lessons in how to achieve the impossible - the story of Teach First. London: Short Books Ltd.

Williams, F. 2004. "What matters is who works: why every child matters to New Labour. Commentary on the DfES Green Paper Every Child Matters." Critical Social Policy 24: 406-427.

Zeichner, K. 2014. "The Struggle for the Soul of Teaching and Teacher Education in the USA." Journal of Education for Teaching 40 (5): 551-568. 